University of Nebraska - Lincoln

DigitalCommons@University of Nebraska - Lincoln

\title{
Human Trafficking in the United States. Part II. Survey of U.S. Government Web Resources for Publications and Data
}

Anchalee (Joy) Panigabutra-Roberts

University of Nebraska - Lincoln, apanigab@utk.edu

Follow this and additional works at: https://digitalcommons.unl.edu/libraryscience

Panigabutra-Roberts, Anchalee (Joy), "Human Trafficking in the United States. Part II. Survey of U.S. Government Web Resources for Publications and Data" (2012). Faculty Publications, UNL Libraries. 291. https://digitalcommons.unl.edu/libraryscience/291

This Article is brought to you for free and open access by the Libraries at University of Nebraska-Lincoln at DigitalCommons@University of Nebraska - Lincoln. It has been accepted for inclusion in Faculty Publications, UNL Libraries by an authorized administrator of DigitalCommons@University of Nebraska - Lincoln. 


\title{
Human Trafficking in the United States. Part II. Survey of U.S. Government Web Resources for Publications and Data
}

\author{
Anchalee Panigabutra-Roberts \\ University of Nebraska-Lincoln Libraries, Lincoln, Nebraska
}

\begin{abstract}
This second part of a two-part series is a survey of U.S. government web resources on human trafficking in the United States, particularly of the online publications and data included on agencies' websites. Overall, the goal is to provide an introduction, an overview, and a guide on this topic for library staff to use in their research and instruction services, as well as to benefit new researchers, students, government agencies, nongovernmental organizations (NGOs), social service providers, and others exploring this topic.
\end{abstract}

Keywords: human trafficking, U.S. government agencies, websites, review, publications, data collection

\section{Introduction}

As Part I suggested, anti-trafficking activities in the United States involve many parties. In Part II, U.S. government agencies' websites and pertinent documents are explored. This article limits its coverage to only the major U.S. federal government agencies, since they are the major players in antitrafficking activities in both law enforcement and victim services.

The author wishes to thank the editor and the anonymous readers for Behavioral E Social Sciences Librarian, and colleagues Kathleen Johnson and David Tyler, both at the University of Nebraska-Lincoln Libraries, for their editorial feedback and comments, which strengthened this article tremendously. Correspondence: Anchalee Panigabutra-Roberts, Metadata \& Multicultural Services Librarian \& Women's and Gender Studies Faculty \& Liaison, University of Nebraska- Lincoln Libraries, 322E Love Library, PO Box 884100, Lincoln, NE 68588-4100; email aroberts4@unl.edu 


\section{Methodology}

For this article, I explored federal agencies' websites, starting with the U.S. Department of State's Office to Monitor and Combat Trafficking in Persons (G/TIP) website (http://www.state.gov/j/tip/index.htm) and also consulting Trafficking in Persons Report (2011) and U.S. Attorney General's Annual Report to Congress and Assessment of U.S. Government Activities to Combat Trafficking in Persons (2011) to ensure a comprehensive coverage of U.S. federal government agencies active in the anti-human-trafficking activities. I include only published data and identify the unpublished data whenever possible. The focus of each review is on the following subtopics:

- Scope of responsibility.

- Publication outputs (if any).

- Research activities, grants, and/or other support.

- Data and other resources.

And all of the websites included in this article were last accessed on September 28, 2012. The goal is to provide a guide on this topic for library staff to use in their research and instruction services by illuminating resources produced by the U.S. government agencies on this topic.

\section{Federal Agencies Involving in Antitrafficking Activities in the United States}

The principal agency overseeing antitrafficking activities in the United States and abroad is the U.S. Department of State Office to Monitor and Combat Trafficking in Persons, known as the G/TIP Office. The most comprehensive report on all of the U.S. government's antitrafficking activities is the U.S. Attorney General's Annual Reports to Congress and Assessment of U.S. Government Activities to Combat Trafficking in Persons (U.S. Attorney General 2006-2011). The sections that follow include reviews of websites related to human trafficking created by the major U.S. government (USG) agencies included in these reports.

\section{U.S. Department of State Office to Monitor and Combat Trafficking in Persons (G/TIP)}

The Office to Monitor and Combat Trafficking in Persons, or the G/ TIP Office, is a division of the Under Secretary for Civilian Security, Democracy and Human Rights, under the Secretary of State. Its mandate is to oversee antitrafficking activities in foreign countries and to collaborate with other federal agencies both on transnational trafficking into the United States and on in-country trafficking. 


\section{U.S. Government Response to Human Trafficking (U.S. Government Response)} http://www.state.gov/j/tip/response/index.htm

G/TIP created this website as a brief introduction to other websites for the U.S. government agencies responsible for combating human trafficking, federal laws and legislation, and USG-funded antitrafficking programs and research.

\section{U.S. Government Entities Combating Human Trafficking http://www.state.gov/j/tip/response/usg/index.htm}

This website provides a good overview of all the USG agencies' involvement in antitrafficking activities with listings from the President's Interagency Task Force to the U.S. Equal Employment Opportunity Commission. It lists each agency with its principal role in antitrafficking efforts, including links to its subagencies and relevant publications. (These agencies' websites are reviewed later in this article.) Therefore, this website should be the first stop for library users interested in researching this topic.

\section{U.S. Laws on Trafficking in Persons http://www.state.gov/j/tip/laws/index.htm}

As mentioned in the introduction to Part I, the first modern U.S. antitrafficking law is the Trafficking Victims Protection Act of 2000 (TVPA) (United States 2000a). This website provides a comprehensive listing and the texts of antirafficking laws, from TVPA of 2000 and its reauthorization, up to the William Wilberforce Trafficking Victims Protection Reauthorization Act of 2008, and related legislation.

Publications: Trafficking in Persons (Tip) Reports (2001-2012)

http://www.state.gov/j/tip/rls/tiprpt/index.htm

G/TIP has published TIP reports annually since 2001, with the most current issue being 2012. It is the report mandated by the Congress under Public Law 106-386, titled Victims of Trafficking and Violence Protection Act of 2000 (United States 2000). The TIP report is the U.S. government's monitoring and evaluation instrument on antitrafficking efforts by foreign governments around the world, but it only began to include the evaluation of the United States' own antitrafficking efforts in 2010. G/TIP uses a threetier ranking system based on the criteria set in the Minimum Standards for the Elimination of Trafficking (United States 2000b), with Tier 1 being the highest rank in its evaluation.

Each report includes the nature and scope of trafficking in persons and the governments' anti-trafficking actions in general. Its major components are country reports from $\mathrm{A}$ to $\mathrm{Z}$ with tier rankings of the countries for each evaluative year and the country's prevention, protection, and prosecution 
programs and activities. This annual report serves as a "report card" for each country's antitrafficking activities and guides the U.S. government's decisions on foreign assistance to or enacting sanctions against countries on Tier 3 that do not have adequate antitrafficking efforts (House 2011,2). Each year, foreign governments and NGOs anxiously wait for the report to be released, so that these agencies and NGOs can use it to assess their resource allocations and areas for improvement, especially with an eye to improving each country's ranking if the country is ranked below Tier 1 . They may be wary of the results of U.S. sanctions, which can be very damaging for them. The U.S. Department of State also uses the ranking to assist in its decision making for grant funding in each fiscal year (see Grants and Research Activities subsection). This report is the "must read" for scholars and researchers on human trafficking.

Grants And Research Activities: International Grant Program, http://www.state.gov/j/tip/intprog/index.htm

The G/TIP Office offers competitive foreign assistance grants annually through this program, to combat sex and labor trafficking with the three Ps: prevention, protection, and prosecution; a fourth P, partnership, has been added in recent years. These grants are geared towards action-based antitrafficking programs. The goal of the grant program is to help improve antitrafficking programs in countries on the Tier 3 and Tier 2 watch list by giving them the funding priorities.

The grant competition announcement usually occurs in October with the deadline for Requests for Statements of Interest (RSOIs) in November. If the RSOIs pass the technical requirement and the first round of approval, then the requesters are asked to submit full proposals later in the spring of the following year. (See grants.gov for the submission process.)

Grants and Research Activities: U.S. Government-Funded Antitrafficking Programs http://www.state.gov/i/tip/response/grants/index.htm

The G/TIP Office website also lists antitrafficking programs funded by U.S. government agencies. The list of funded projects for each fiscal year (FY) are listed on this webpage (2008-2010), with a cross-reference to the archive for FY2002-2008: http://2001-2009.state.gov/g/tip/rls/rpt/index.htm.

G/TIP provided funding for prevention, protection, prosecution, and partnership in antitrafficking activities, from legal assistance, to fair trade (Slavery Footprint), action research (e.g., Virginia State University for research on domestic servitude in Ghana), and other sorts of research studies (such as a study by the Urban Institute). Other major grantors are the U.S. Department of Homeland Security, Department of Justice 
and National Institute of Justice, and Department of Health and Human Services. (See each agency's information in the following sections for more details.)

\section{Research}

http://www.state.gov/j/tip/response/research/index.htm

The G/TIP Office supports and funds evidence-based research that supports countertrafficking activities. The office also compiles information on research funded across the U.S. government, which is listed on this website in the link to "chart" and embedded as a spreadsheet listing research with details on fiscal years (2001-2010): funding bureaus, countries where trafficking occurs or is under study, grantees, descriptions of the research, and hyperlinks (webpages) to research projects' websites for some projects, if available. One can also find some of the research reports at the specific agencies' websites.

\section{Human Smuggling and Trafficking Center (HSTC)} http://www.state.gov/m/ds/hstcenter

Established in 2004 under the Intelligence Reform and Terrorism Prevention Act of 2004, Section 7202 (United States 2004), as a unit under the Department of State's Bureau of Diplomatic Security, the Human Smuggling and Trafficking Center (HSTC) acts as a centralized clearinghouse for intelligence on alien smuggling, trafficking in persons, and criminal support of clandestine terrorist travel. The center's goal is to support the prevention and deterrence of human smuggling and trafficking, the investigation and prosecution of the smugglers and traffickers, and the protection of and assistance for the victims (Human Smuggling and Trafficking Center [U.S.] 2004).

The HSTC is staffed by the participating agencies: Department of State, Department of Homeland Security, Department of Justice, Office of the Director of National Intelligence, and other government agencies (http:// www.state.gov/m/ds/hstcenter/agencies/index.htm). Thus, its functions are mostly internal to the participating agencies due to its role as an intelligence unit. The website does have some public, unclassified information at http://www.state.gov/m/ds/hstcenter/c40292.htm . This section includes the original documents for the establishment of the center, and other publications focused mostly on sex trafficking in Tenancingo, Tlaxcala, in Mexico, especially detailing how the traffickers trafficked women and girls from Mexico, mostly poor and indigenous, and women and migrants from Latin American countries en route to the United States via Mexico (Human Smuggling and Trafficking Center [U.S.] 2010). Since this unit is established mostly for intelligence purposes, public information is limited and is not a priority. Other agencies, such as the Depart- 
ment of Justice in the following section, provide more comprehensive public information on human trafficking in the United States.

\section{U.S. Department of Justice (DOJ)}

While the G/TIP focuses on global antitrafficking efforts, the DOJ is the principle government agency overseeing antitrafficking efforts within the United States and its territories, especially for the law enforcement aspects. Under the DOJ, the agencies working on antitrafficking are the National Institute of Justice, Bureau of Justice Assistance, Bureau of Justice Statistics, Office for Victims of Crime, Office of Justice Programs, and Federal Bureau of Investigation. Details on each agency's antitrafficking functions are described next.

National Institute of Justice (NIJ)

The NIJ functions as the research arm for the Department of Justice and presents a good introductory website on "human trafficking" at http:// www.nij.gov/nij/topics/crime/human-trafficking/welcome.htm . While this provides a good introduction to human trafficking based on research findings either published or sponsored by NIJ, the agency needs to update the content on this page from more current NIJ research to be found in the NIJ publications database, Topical Collection: Human Trafficking (http://nij. ncjrs.gov/App/publications/Pub_search.aspx?searchtype=basic\&catego $\underline{\text { ry }=99 \& \text { location=top\&PSID }=25)}$. This collection currently has 38 publications, 10 published by NIJ and 28 sponsored by NIJ (National Institute of Justice [U.S.] 2012).

A caveat for NIJ research reports is that they are quite lengthy (255 and 158 pages, for example). Some researchers have published their NIJ studies in scholarly journals, but some have not. For an example of a scholarly journal article based on NIJ research, see Farrell, McDevitt, and Fahy (2010), which is based on their NIJ research grant entitled Understanding and Improving Law Enforcement Responses to Human Trafficking (Farrell et al. 2008). The reports of past projects can also be found in the National Criminal Justice Reference Service (NCJRS) Abstract Database: https://www.ncjrs. gov/App/AbstractDB/AbstractDBSearch.aspx (National Criminal Justice Reference Service [U.S.] and National Institute of Justice [U.S.] 1997-2012).

Since NIJ is the research arm for the Department of Justice, it also provides funds for research projects on human trafficking with the foci on:

- The nature and extent of human trafficking.

- Detecting and investigating traffickers.

- Prosecuting traffickers.

- Services for trafficking victims (National Institute of Justice 2007). 
Grant funding and awards and descriptions on the nature of research NIJ would support can be found on this website: http://www.nij.gov/ funding/current.htm. The lists of awards made by NIJ can be found at http://www.nij.gov/nij/funding/awards/welcome.htm. For example, the solicitation for the FY 2011 is Research and evaluation on trafficking in persons: https://www.ncjrs.gov/pdffiles1/nij/s1000974.pdf. With awards of up to $\$ 1,000,000$, this solicitation targeted research focusing on labor trafficking (LT) in the United States, especially on how state and local law enforcement respond to LT with investigation, how traffickers and facilitators operate, and on evaluations of countertrafficking tools or programs. From this solicitation, NIJ funded the following projects ${ }^{1}$ :

1. Human trafficking organizations and facilitators: A detailed profile and interviews with convicted traffickers in the United States (grantee: Abt Associates, Inc.).

2. Understanding the organization, operation and victimization of labor trafficking in the United States (grantee: Urban Institute).

3. Improving trafficking victim identification: Evaluation and dissemination of a screening tool (grantee: Vera Institute of Justice) (National Institute of Justice [U.S.] 2011).

Bureau of Justice Assistance (BJA): Anti-Human Trafficking Task Force Initiative

http://www.ojp.usdoj.gov/bja/grant/httf.html

The BJA created human trafficking (HT) task forces as one of its programs to provide funding for state, local, or tribal law enforcement agencies and service providers through the grant award program Enhanced Collaborative Model to Combat Human Trafficking (a joint solicitation of BJA and the Office for Victims of Crime). See this closed solicitation for FY2012 for more information at https://www.bja.gov/ Funding/12HumanTraffickingSol.pdf. Currently there are 40 task forces funded by BJA and the Office for Victims of Crime (OVC) as shown in Figure 1 (U.S. Bureau of Justice Assistance and Office for Victims of Crime 2009). From these task forces, there are many resources being created via the process shown in the diagram in Figure 2.

Human Trafficking Reporting System (HTRS)

http:/ / bjs.ojp.usdoj.gov/index.cfm?ty=dcdetail\&iid=343\#documentation

The Human Trafficking Reporting System (HTRS) was developed as a project by Northeastern University's Institute on Race and Justice, in partnership with the Urban Institute, Justice Policy Center, and Bureau of Justice Statistics, with funding from the Department of Justice, to collect data on alleged human trafficking incidents from state and local law enforcement agencies via BJA/OVC Human Trafficking Task Forces (already de- 


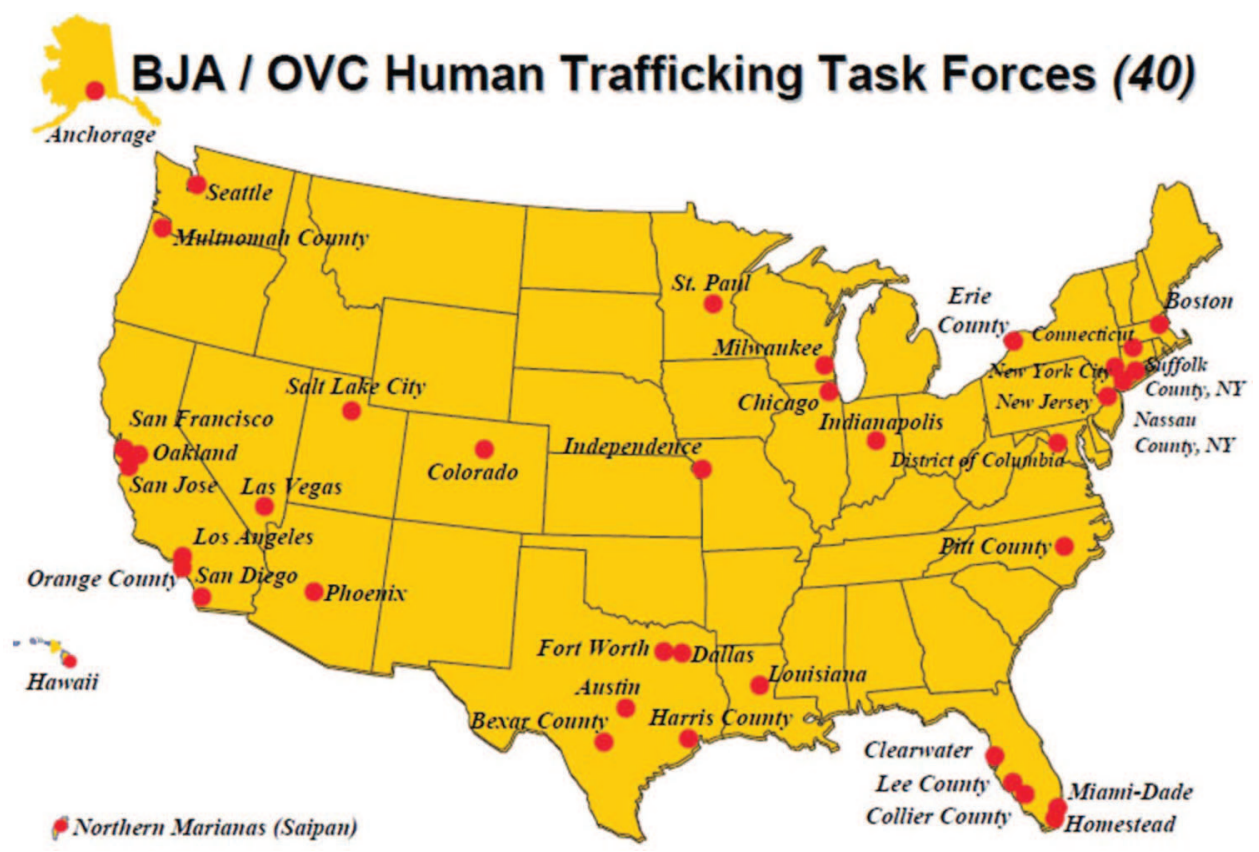

Figure 1. BJA/OVC Human Trafficking Task Forces (40).

\section{BJA Task NIJ Grant to \\ Forces: $2008=\Rightarrow \quad$ NEU and \\ $38 \mathrm{TF}$
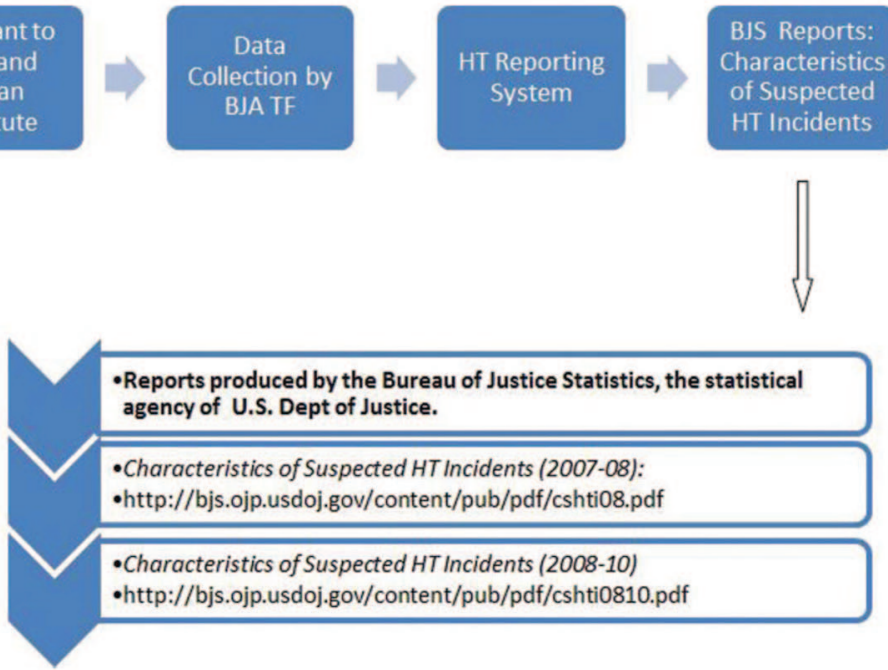

Figure 2. The genesis of the Human Trafficking Reporting System/Data Collection and Reporting Project. 
scribed). HTRS is, so far, the only system that captures information on human trafficking investigations conducted by state and local law enforcement agencies in the United States. (See also the FBI information later in this article, for future plans for the FBI's data collection and reporting.)

\section{Bureau of Justice Statistics (BJS): Publications and Data}

http:/ / bjs.ojp.usdoj.gov/index.cfm?ty=dcdetail\&iid=343\#documentation

The Bureau of Justice Statistics (BJS) is the statistical agency of the U.S. Department of Justice. From HTRS's data collection, BJS has published two volumes in the series Characteristics of Suspected Human Trafficking Incidents Series (2007-2008; 2008-2010) (Kyckelhahn et al. 2009; Banks, Kyckelhahn, and U.S. Bureau of Justice Statistics 2011). There are just two publications to date. They are accompanied by downloadable data from the website, in ASCII format or spreadsheets, from the original research project by Northeastern University funded by NIJ, under the Human Trafficking Data Collection and Reporting Project: http://www.humantrafficking.neu.edu .

Each report collected the data from BJA Human Trafficking Task Forces since 2008, with retrospective data file from 2007, which resulted in these two publications. The data were submitted online by a designated data reporter from each task force (38 in the first publication, and 42 task forces in the second one). The reporter recorded human trafficking incidents on a monthly basis using two forms online: Suspect information form or Victim information form (Kyckelhahn et al. 2009, 11-12). An incident was identified once an investigation produced information about potential suspects or victims. The data include information on the incidents (status of the investigation, type of human trafficking, lead agency, number of known victims, number of known suspects, location, etc.). Victims' data are gender, age, and citizenship status. Suspects' information includes gender, age, race/Hispanic origin, citizenship, arrests, type of arrest, charges, status of case, and so on. The 2011 publication has good highlights of the findings. This reporting system is the best data collection mechanism on human trafficking in the United States to date.

\section{Office for Victims of Crime (OVC)}

From the OVC's main webpage, http://www.ojp.usdoj.gov/ovc/ welcome.html the index in "Topics A-Z's alphabetical list" leads to OVC's website on human trafficking: http://ovc.ncjrs.gov/topic. aspx?topicid $=37$. OVC collaborated with BJA to operate antitrafficking task forces; therefore, the publications from the task forces listed at BJA are also cross-listed on this website. But some publications are unique materials created by OVC, such as Anti-Human Trafficking Task Force Strategy and Operations EGuide at https://www.ovcttac.gov/taskforceguide. This is a PDF-based guide (e-document) with navigation via hyperlinks among the sections, but also with the option to download the entire guide 
as a PDF document. ${ }^{2}$ Since it is an electronic book, a static PDF guide with navigation, the information has not been updated as of last access (September 28, 2012). The content of the guide is based on the experience BJA has gained from its anti-humantrafficking task forces for 5 years since its initiative to create these task forces (U.S. Department of Justice, Bureau of Justice Assistance, and Office for Victims of Crime 2011). Thus, the OVC and BJA released this e-guide in 2011 to support ongoing task forces, new ones, those in law enforcement, and victim service providers. It includes information on how to create new task forces and to operate them, with a section on federal and state legislations (as of January 2011). (See the Polaris Project website, http://www.polarisproject.org, for comprehensive details on state legislation that will continue to be updated.) The target audience is law enforcement personnel and service providers, that is, the members of the task forces. The guide has a victimcentered approach with training tools (text and videos) and best practices. Resources for prosecutors list a manual for lawyers and guides for legal advocates and legal services providers. This is the most comprehensive published document/ guide for law enforcement and victim service providers on human trafficked victims in the United States available to date.

Office of Justice Programs (OJP)

This agency provides a fact sheet on human trafficking at http:// www.ojp.usdoj.gov/newsroom/factsheets/ojpfs_humantrafficking.html. This webpage alerts one to a publication not listed in the NIJ topical collections, such as the Office of Juvenile Justice and Delinquency Prevention (OJJDP) bulletin Effects of Federal Legislation on the Commercial Sexual Exploitation of Children (Adams et al. 2010). The bulletin does include a link to the full report in the NCJRS Database (Small et al. 2008) at https://www. ncjrs.gov/pdffiles1/ojjdp/grants/222023.pdf . Other reports on children as trafficked victims are filed under the NIJ's Topical collection, Child abuse and maltreatment: http://nij.ncjrs.gov/App/publications/Pub search.asp $\underline{x}$ ? searchtype $=$ basic\&category $=99 \&$ location $=$ top\&PSID $=66$. (See also the FBI's Innocence Lost National Initiative).

Federal Bureau of Investigation (FBI): Human Trafficking http://www.fbi.gov/about-us/investigate/civilrights/ human trafficking

The FBI Civil Rights Division designated human trafficking/involuntary servitude as one of its four priority issues. The Human Trafficking - FBI Initiatives page (http://www.fbi.gov/about-us/investigate/civilrights/human_trafficking/initiatives) provides detailed information on the role of the FBI in combating labor exploitation in industries, such as agriculture and domestic service, and in forced prostitution and/or slave labor. The FBI participates in the BJA task forces and other working groups; thus, it 


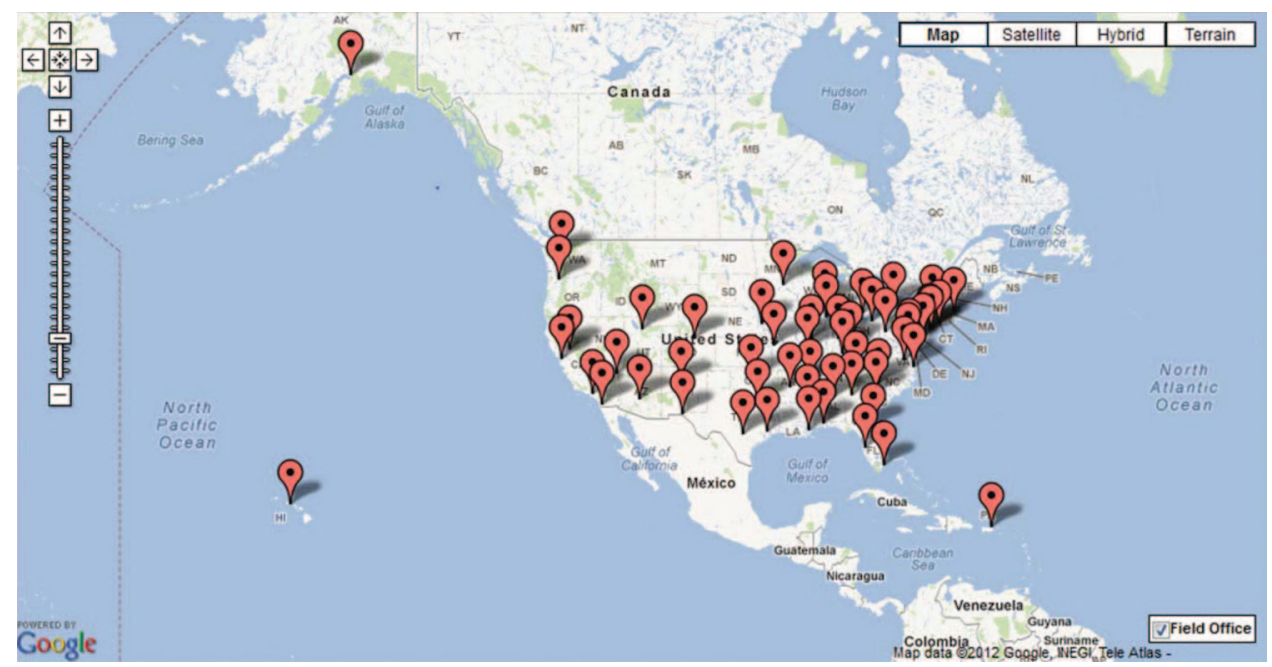

Figure 3. Local FBI offices.

collaborates in the investigation, prosecution, and provision of services to human trafficked victims. It also has its own victim specialists who work alongside the victim specialists from the U.S. Attorney offices. For example, in Nebraska, the FBI Unit in Omaha works with the U.S. Attorney office that covers Omaha, NE, and Council Bluffs, IA, areas, with both offices' victim specialists working hand-in-hand on cases and training.

The FBI-Human Trafficking website dedicated to human trafficking information lists its hotline services with comprehensive options, such as access to interpreters and after-hours information in multiple languages (English, Spanish, Russian, and Mandarin) and nondiscriminatory services (new laws provide options for trafficking victims regardless of immigration status). It also includes the updates and press releases on the results of cases investigated by the FBI offices throughout the United States, except for the cases with ongoing investigations.

For statistical data, the FBI page provides a link to the aforementioned Bureau of Justice Statistics' Trafficking Incidents. The Stories and Features section lists the FBI's prominent human trafficking cases, including the FBI's biggest labor trafficking case so far, of the labor trafficking of Thai laborers in Hawaii. For human trafficking cases investigated by each FBI jurisdiction, the cases can be found at each FBI's state/local office's website via the Local FBI Offices webpage at: http://www.fbi.gov/contact-us/ field (U.S. Federal Bureau of Investigation 2012). Then one can select each FBI office from the interactive Google Map (Figure 3).

Each local office lists its own initiatives and stories of cases investigated by the office. Not all FBI Offices are equal in terms of how they operate and prioritize human trafficking cases, which is somewhat based on their ability to secure additional grants. For example, the FBI in Omaha, $\mathrm{NE}$ had special agents dedicated to human trafficking with funding from 
the Innocence Lost Initiative. In another instance, the FBI in Kansas City, $\mathrm{MO}$ was chosen (along with Atlanta; El Paso, Texas; Los Angeles; Memphis, Tenn.; and Miami) to be a part of the Pilot Anti-Trafficking Coordination Teams (ACTeams), a multi-agency effort to improve the investigation and prosecution of human trafficking cases: http://www.fbi.gov/ news/pressrel/press-releases/departments-of-justice-homeland-securityand-labor-announce-selection-of-anti-trafficking-coordination-teams .

As for the FBI's data, the TIP 2011 report (U.S. Department of State, Office to Monitor and Combat Trafficking in Persons 2011a, 373) addresses the data issue and the plan for the FBI to implement a data system to be included in its annual statistics by 2013. For past and current FBI data on human trafficking, refer to the U.S. Attorney General's Annual reports to Congress and assessment of U.S. government activities to combat trafficking in persons (U.S. Attorney General 2006-2011).

Federal Bureau of Investigation (FBI): Innocent Lost National Initiative http://www.fbi.gov/about-us/investigate/vc_majorthefts/cac/ innocencelost

This is a significant and separate initiative established in June 2003 by the FBI, in conjunction with the Department of Justice Child Exploitation and Obscenity Section and the National Center for Missing and Exploited Children, to address the problem of domestic sex trafficking of children in the United States. The site lists statistics, a hotline and a website to report online. Some research and reports are cited in the publications under "Resources" and "Fact Sheets" on the "Innocence Lost National Initiative" webpage. Research studies on this topic can best be found in the NIJ's topical collections on human trafficking and child exploitation, as mentioned earlier.

In summary, DOJ is the de facto department that oversees law enforcement of human trafficking in the United States in collaboration with other USG agencies. As an observation, it is interesting to note that the DOJ's Office on Violence Against Women, http://www.ovw.usdoj.gov/index. html, does not list 'human trafficking' as one of the areas of focus for the office, despite the high level of antitrafficking activities in the DOJ.

\section{Department of Homeland Security (DHS)}

Human Trafficking

http://www.dhs.gov/topic/human-trafficking

The Department of Homeland Security (DHS) has centralized the webpage for all of its agencies' antitrafficking activities: U.S. Immigration and Customs Enforcement (ICE), Customs and Border Protection (CBP), U.S. Citizenship and Immigration Services (USCIS), and Federal Law Enforcement Training Center (FLETC). DHS's antitrafficking activities focus on actions and collaborations with other agencies on HT's law/border en- 
forcements, public awareness campaigns, and victim services. This website provides no information on how data are collected or reported. DHS's data on human trafficking, however, can be found in the U.S. Attorney General's Annual Reports to Congress and Assessment of U.S. Government Activities to Combat Trafficking in Persons (U.S. Attorney General 2006-2011).

More information on DHS's antitrafficking activities - based on the four ' $\mathrm{P}$ 's of protection, prevention, prosecution and partnership model-is a part of DHS's Blue Campaign's website: http://www.dhs.gov/files/programs/ gc 1270739792024.shtm. DHS lists its divisions involved in anti-human trafficking and its other partners on this site. For future developments on antitrafficking, the stakeholders' meeting organized by the DHS Blue Campaign in January 2012 listed many new initiatives, such as DHS's public awareness campaign, TIP 101 (see next subsection), new programs with Department of Transportation, such as the Blue Lightning Initiative (training for airline personnel), training for local motor vehicle departments (DMVs), and Federal Emergency Management Agency (FEMA) training for first responders (U.S. Department of Homeland Security 2012).

DHS's Blue Campaign is also on Facebook: http://www.facebook. com/bluecampaign. By clicking "like" on this Facebook page, one can access the page and find a new resource on anti-human trafficking resources for business, http://www.dhs.gov/files/programs/gc 1298392290730. shtm, which has good resources on awareness and has training tools on human trafficking, labor practices, and consumers awareness.

TIP 101 Training

http://www.dhs.gov/xlibrary/training/dhs awareness training fy12/ launchpage.htm

The Human Trafficking Awareness Training (TIP 101 Training) is a Webbased, self-paced training module created by DHS. It takes about 20 minutes, depending on the self pace, to complete the module. Viewers will gain a fairly comprehensive understanding of human trafficking. The module includes definitions of trafficking versus smuggling, explanations of how victims are exploited, victims' vignettes, causes of and vulnerability to human trafficking, how to identify red flags, and national hotline numbers to report incidents of human trafficking. Web links to resources provide downloadable documents and links to other agencies involved in antitrafficking activities, as well.

U.S. Citizenship and Immigration Services (USCIS), Victims of Human Trafficking $\mathcal{E}$ Other Crimes

http://www.uscis.gov/portal/site/uscis/menuitem.eb1d4c2a3e5b9ac89243c6a7543f6d1a/?vgnextoid =829c3e4d77d73210vgnvcm100000082ca60a $\underline{\text { rcrd\&vgnextchannel=829c3e4d77d73210vgnvcm100000082ca60arcrd }}$ 
Responsible for providing immigration relief to the victims of human trafficking, USCIS created this webpage for the special visas for victims of human trafficking. The two visas relevant to trafficked victims are " $\mathrm{T}$ " Nonimmigrant Status and " $U$ " Nonimmigrant Status. You can be eligible for the $T$ visa if you can assist law enforcement in the prosecution of the traffickers, with the proof that you would suffer hardship or harm if removed from the United States, and/or for the U visa, if you are a victim of physical or mental abuse as a result of having been a victim of criminal activity.

This page also features comprehensive information on the visas and eligibility requirements, a list of application forms for the visas, other tools for training and resources, and links to other agencies and NGOs providing services for trafficked victims. If you have been through an immigration process, however, you know that there are "unwritten rules" or tips known only by immigration lawyers or those who have more experience or training with the visa application process. Victims can be from anywhere in the world and may not be able to speak English. Unfortunately, the only other language option for the webpage is in Spanish. Thus, better victim support is needed, especially for legal, language, and culturally appropriate services. However, when compared to other agencies, the webpage is fairly comprehensive for the requisite information for immigration services for trafficked victims. For more comprehensive information on victim assistance, especially for service providers, see the Administration for Children and Families under the Department of Health and Human Services (ACF HHS), which is the agency responsible for services for trafficked victims, in the DHHS section in this article.

Along the sidebar of the webpage, there is a link to Federal Law Enforcement Training Center's (FLETC) Human Trafficking Training Program, which is meant for law enforcement to use via a secure website. DHS has created a separate training/awareness program for the public, that is, the TIP 101 Training already mentioned.

\section{U.S. Immigration and Customs Enforcement (ICE)}

As the principal investigative arm of DHS, ICE investigates human smuggling and human trafficking cases, especially when immigration is involved. ICE lists "human trafficking" under the "investigations" tab on its main website: http://www.ice.gov/human-trafficking. The agency uses this website to solicit tips from the public via ICE's Tip Line. Other information is hidden in a set of links that can be expanded and includes brief details of recent cases under investigation, public awareness campaigns, the DHS Blue Campaign, and ICE's public awareness campaign "Hidden In Plain Sight," which is linked to a news release about the campaign, but with no links to the campaigning tools, except for ICE's public service announcements (PSAs) listed on the main website. 'Support for Victims" includes a brief detail on ICE"s Victims Assistance Program. 
"Project STAMP" (Smuggler and Trafficker Assets, Monies and Proceeds) provides brief information on how ICE can track down traffickers through their money transactions. The "Our Partners" section provides links to U.S. Customs and Border Protection and to USCIS. The bottom of the page lists recent news by the most current date, with extensive details on the cases of human trafficking after the investigations can become public, such as charges, indictment, and so on.

On the sidebars, there are also links to the Department of State's Human Smuggling and Trafficking Center, to ICE Fact sheets ${ }^{3}$ (with details on ICE's responsibility on anti-trafficking efforts in collaboration with law enforcement and victim-service providers), and to ICE PSA ${ }^{4}$ videos (in full and short versions, Spanish, any age and prostitution versions). Other links with DHS are the PDF documents for Blue Campaign Fact Sheet and the Continuous Presence for Trafficking Victims, which allows trafficked victims to remain in the United States for 1 year during the investigation (U.S. Immigration and Customs Enforcement 2010). (See also the Department of Health and Human Services "Rescue \& Restore Campaign Fact Sheets": http:// www.acf.hhs.gov/programs/orr/resource/rescue-restore-campaign-factsheets under "Certification for Victims of Trafficking.")

Thus, the ICE Human Trafficking website aims at hotlines to solicit tips, services for victims, and public awareness campaigns, with news on cases investigated by ICE. There is no indication of data gathering or of substantial publications or research on this website. ICE's data on human trafficking can be best found in the U.S. Attorney General's Annual Reports to Congress and Assessment of U.S. Government Activities to Combat Trafficking in Persons (U.S. Attorney General 2006-2011).

\section{U.S. Department of Health and Human Services, Administration for Children and Families (ACF DHHS)}

The Campaign to Rescue \& Restore Victims of Human Trafficking http://www.acf.hhs.gov/trafficking/index.html

The U.S. Department of Health and Human Services, Administration for Children and Families (ACF DHHS) is the agency that is responsible for services for the victims of human trafficking. Thus, the main website for DHHS's Campaign to Rescue E Restore Victims of Human Trafficking is housed under this agency. This Anti-Trafficking in Persons Program aims at victim identification and public awareness, and assistance for the victims of human trafficking. DHHS collaborates with the Office of Refugee Resettlement to provide services to foreign nationals who are victims of HT. The agency also oversees the National Human Trafficking Resource Center (NHTRC), a national, toll-free hotline for the human trafficking field in the United States. Since September 2010, DHHS awarded a 3-year grant to the Polaris Project to operate the hotline and its web por- 
tal ${ }^{5}$ : http://www.polarisproject.org/what-we-do/national-human-trafficking-hotline/the-nhtrc/overview. Thus, its hotline statistics were reported as a part of DHHS's annual report in FY2010 (U.S. Attorney General 2011, 35-38).

Rescue \& Restore Campaign Coalitions

http://www.acf.hhs.gov/trafficking/coalition/index.html

These nationwide coalition partnerships, established during President George W. Bush's presidency, were organized to "disseminate campaign information and resources to intermediaries who may come in contact with victims of trafficking to inform them of the services available to victims in their communities" (website). The coalition partners include local governments, civic groups, community health providers, faith-based organizations, nonprofit organizations, and social service organizations. Details on the members of the coalitions can be found under "Contact Information for Coalitions" at http://www.acf.hhs.gov/programs/orr/resource/contactinformation-for-coalitions. These coalitions are separate entities from the BJA Anti-Trafficking Task Forces and are funded by DHHS.

\section{DHHS Publications}

1. Services Available to Victims of Human Trafficking (U.S. Department of Health and Human Services 2012b): http://www.acf.hhs.gov/programs/orr/resource/services-available-to-victims-of-human-trafficking. This DHHS downloadable publication in PDF format is a comprehensive and up-to-date guide for victim services and the "must have" publication for service providers. Since DHHS uses contracts to NGOs for their services via grant funding, service providers need to make sure to use the latest edition. The DHHS service providers can change from funding year to year. For example, the U.S. Conference of Catholic Archbishops used to receive grants from DHHS to provide services and case management of foreign victims of human trafficking, but the funding stopped for them last year due to some problems with contraception issues.

2. Rescue $\mathcal{E}$ Restore Campaign fact sheets: http://www.acf.hhs.gov/trafficking/about/factsheets.html. Service providers will find these multilingual fact sheets in English, with some in Spanish, Polish, Russian, and Traditional Chinese, useful. The sheets offer facts about human, sex, and labor trafficking (how victims are trafficked, etc.), assistance available to the victims (immigration, jobs, shelters, etc.), and the U.S. government's certification requirements for victims ( $T$ Visa, Continuous Presence, etc., with samples of certification letters) (U.S. Department of Health and Human Services 2012a).

3. Campaign posters and brochures, "Look Beneath the Surface" (Figure 4) in English, Spanish, Indonesian, Chinese, and Korean, can be downloaded from http://www.acf.hhs.gov/programs/orr/resource/download-campaign-posters-and-brochures (U.S. Department of Health and Human Services 2012). 


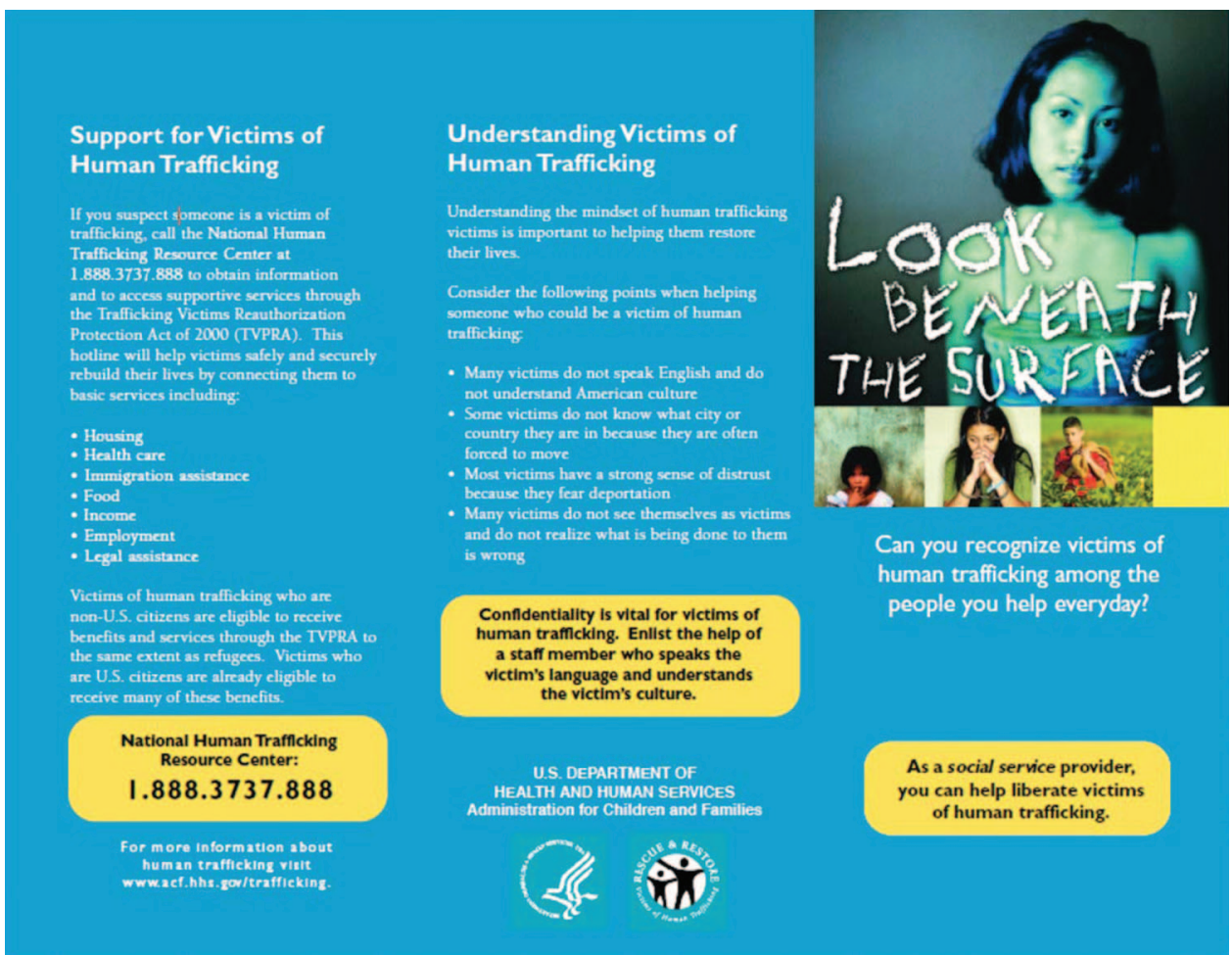

Figure 4. Poster: "Look Beneath the Surface."

\section{U.S. Department of Defense (DOD)}

Sparked by a string of problems of UN peacekeepers' human trafficking cases involving sexual abuse and exploitation, and labor trafficking among military contractors (Qu'enivet 2007; Kanetake 2010; U.S. Department of State, Office to Monitor and Combat Trafficking in Persons 2007), the U.S. Department of Defense (DOD) responded by creating the DOD Trafficking in Persons (TIP) Program and its "zero tolerance policy" in 2004 (U.S. Department of Defense, Office of the Inspector General 2004). Currently, there are three main websites created by DOD focusing on TIP.

Combating Trafficking in Persons - U.S. Department Of Defense http://ctip.defense.gov

This DOD general website on trafficking in persons provides general information on definitions and on required training programs and tools for U.S. military personnel, especially those deployed overseas. It covers 
all forces; Army, Navy, Marines, and Air Force. The main page introduces the definitions of trafficking in persons, focusing on sex and labor trafficking, child exploitation, and on especially child soldiering. ${ }^{6}$ The core of this site is the "Required Training" modules (PowerPoint slides, memos, etc.): http://ctip.defense.gov/requirement.html, which focuses on sex and labor trafficking. Although child soldiers were listed as a type of human trafficking, DOD does not include this type of trafficking in its directive or training tools, nor as a code in the DOD database. That is because, according to the Child Soldiers Prevention Act (United States 2007), the Secretary of State is mainly responsible for investigating the practice of child soldiering via U.S. diplomatic missions overseas and using nonmilitary means, such as sanctions on financial and military assistance, rather than using armed forces, to enforce a ban on child soldiering. The Secretary of State is also mandated to include "child soldiers" in its Human Rights Reports submitted annually to the Congress (U.S. Department of State 19792011). Other entities involved in the monitoring of "child soldiers" issues, besides the Department of State, are the Department of Labor and the Department of Defense. Other international entities working on this issue include the International Labor Organization, UN Children's Fund, and Human Rights Watch. Thus, the DOD's main concerns, policies, and training on TIP focus only on sex and labor trafficking.

DOD Office of Inspector General (IG) CTIP Page

http://www.dodig.mil/inspections/ipo/combatinghuman.htm

Based on the DOD Office of Inspector General (IG) mission as an independent agency to provide oversight of the U.S. Department of Defense, the agency has created a website to focus on policies, reports, and other documents associated with DOD's Combatting Trafficking in Persons mission. DOD IG conducts investigations by reviewing military contracts to assess whether the contractors may engage in trafficking in persons. The results of the investigations are listed on this page from 2010-2012 for different geographic regions of the world, with the links to DODIG CTIP reports (2006, 2010-2012): http:// www.dodig.mil/Inspections/IPO/ DoDIGTIPreport.htm.

\section{DOD Instructions}

This section lists general policy and guidelines on CTIP and military personnel, including the background and history of DOD CTIP and criminal jurisdiction concerning CTIP. It also includes a link to the Federal Acquisition Regulation (FAR) amendment to include a requirement that contracts include a provision "that authorizes the department or agency to terminate the contract, if the contractor or any subcontractor engages in trafficking in persons" (U.S. Department of Defense, General 
Services Administration, and National Aeronautics and Space Administration 2009, 2741).

\section{DOD and Human Trafficking Database}

Based on the CTIP 2011 report (U.S. Department of Defense, Office of the Inspector General 2011, 8), DOD has created two new codes for human trafficking offense for its Defense Incident-Based Reporting System. Thus, this enables agencies in DOD to record the incidents accordingly and also to produce the CTIP annual reports with less time in searching for data.

\section{Department of Labor (DOL)}

Although labor trafficking is considered a major type of human trafficking in the United States, DOL does not have a webpage dedicated to human trafficking, as was the case with other agencies. DOL also frames human trafficking as women's and international child labor issues based on the two webpages dedicated, but not well listed or indexed, for the $O f$ fice of Child Labor, Forced Labor, and Human Trafficking (OCFT) and its Women's Bureau's Trafficking in Persons: A Guide for Non-Governmental Organizations (2002). However, the Women's Bureau guide has not been updated since 2002. DHHS's human trafficking website has more up-to-date information. In general, the information in this section is relevant for trading and acquisition practices and international agreements that will impact products imported to the United States, for consumer awareness, and for researchers interested in child labor problems in other countries and their relations to U.S. laws and regulations.

Office of Child Labor, Forced Labor, and Human Trafficking (OCFT) http://www.dol.gov/ilab/programs/ocft

OCFT is a part of the U.S. Department of Labor's Bureau of International Labor Affairs (ILAB), created in 1993 in response to a request from the Congress to investigate and report on child labor around the world. OCFT has also created a special page on child soldiers or children affected by armed conflict abroad: http://www.dol.gov/ilab/programs/ocft/ armedconflict.htm.

\section{OCFT Publications}

http://www.dol.gov/ilab/media/reports/iclp/main.htm

This is the main website for all publications published by and related to OCFT, with references to documents and reports associated with other websites, such as different reports listed under "Laws \& Regulations." With respect to OCFT's major publications, the agency has published two 
notable series of publications and several other separate reports:

1. Advancing the Campaign Against Child Labor series (2001-2004), available in html and PDF versions or in print version on order. The series published reports on the assessment and evaluation of various aspects of child labor at the international and large-scale level. The reports cover the evaluation of national and international financial resources allocated for children's basic education and child welfare, and for the elimination of child labor, the evaluation of strategies to eliminate the worst forms of child labor around the world, the evaluation of countries' efforts to eliminate child labor practices, and the International Labor Organization's projection on the campaign against child labor.

2. By the Sweat $\mathcal{E}$ Toil of Children series (1994-2000), available in html and PDF versions or in print version on order. This Congressionally mandated series includes reports on the economic factors preventing children from access to education, child labor in developing countries, the use of consumer labeling programs to communicate to consumers about child labor via the products, and the use of child labor in agricultural products imported to the United States, for example.

3. Other child labor publications include reports on studies of child labor in different countries, such as Egypt, Rwanda, Suriname, Uganda, and Paraguay, in different industries, and other efforts in combating child labor.

\section{Laws \& Regulations}

http://www.dol.gov/ilab/regs/main.htm

This page lists the laws and regulation relating to trade agreements and acquisition regulations concerning the use of child labor and forced labor. Reports related to different laws and regulations are listed under each law or regulation's webpage. For example, List of Goods Produced by Child Labor and Forced Labor (2011) is listed under the "Trafficking Victims Protection Reauthorization Act" page at OCFT, http://www.dol.gov/ ilab/programs/ocft/PDF/2011TVPRA.pdf, and the annual reports, Findings on the Worst Forms of Child Labor, are listed under the webpage for "The Trade and Development Act" at OCFT, http://www.dol.gov/ilab/ programs/ocft/tda.htm.

\section{U.S. Equal Employment Opportunity Commission (EEOC)}

As stated on the U.S. G/TIP website, "EEOC investigates, attempts to informally resolve, and litigates charges alleging discrimination on the basis of race, color, national origin, sex, religion, age, disability, and genetic information. In appropriate cases, therefore, the EEOC is able to secure civil remedies (e.g., monetary and equitable relief) for trafficking victims" 
(U.S. Department of State, Office to Monitor and Combat Trafficking in Persons 2011b). With this role, the U.S. Equal Employment Opportunity Commission (EEOC) has been successful in some labor trafficking cases in securing financial compensation for labor trafficked victims, while the criminal cases may still be pending, such as in the case of Thai farm workers and Global Horizons, Inc., in Hawaii and Washington State. This example, other cases EEOC has been involved with, and other information on EEOC's actions and plans on antitrafficking activities can be viewed via EEOC's newsroom website: http://www.eeoc.gov/eeoc/newsroom/ trafficking task force.cfm. However, the EEOC has no specific webpage dedicated to human trafficking at this time.

\section{U.S. Department of Agriculture (USDA)}

The usual topics (human trafficking, forced labor, child labor, labor trafficking, and trafficking in persons) were not listed in the A-Z index for the U.S. Department of Agriculture (USDA) website. USDA documents and related websites on human trafficking, as listed next, were found via searching in the search engine at the USDA website with the phrase "labor trafficking":

Consultative Group to Eliminate the Use of Child Labor and Forced Labor in Imported Agricultural Products

http://www.fas.usda.gov/info/child_labor/childlabor.asp

This is a one-webpage document about this consultative group, established by the 2008 Farm Bill to produce guidelines to reduce the likelihood that agricultural products imported into the United States are produced with child or forced labor and to make recommendations to the Secretary of Agriculture. It includes the group's report in PDF format, Consultative Group to Eliminate the Use of Child Labor and Forced Labor in Imported Agricultural Products: Report (2010), http://www.fas.usda.gov/info/Child labor/CGDraftRPTRECS\%20-\%20final\%2012\%2015.pdf.

Questions and Answers about USDA's Guidelines for Eliminating Child and Forced Labor in Agricultural Supply Chains

http://www.fas.usda.gov/info/child_labor/qas\%205_27.pdf

This document includes questions and answers based on USDA's Federal Register Notice to inform the public of the guidelines on April 12, 2011. Thus, research resources on LT victims are not in the purview of the USDA. Such research problems are covered by NIJ via the reports in the topical collections on human trafficking, with individual cases listed on the FBI stories pages and via other resources for general legal cases. 


\section{Department of Education (DOE)}

As a part of the Department of Education (DOE) Office of Safe and Drug-Free Schools, DOE published a fact sheet for schools on Human Trafficking of Children in the United States: http://www2.ed.gov/about/offices/list/osdfs/factsheet.html. It emphasizes known facts on trafficking, especially for the children population in the schools who are vulnerable for sex trafficking, and how to identify victims, with a section on sex-related trafficking victims, hotline numbers to report suspected cases, and links to other U.S. government websites and related resources. As noted on the website, the websites cross-listed on this page were accessed on June 26, 2007; thus, the information is outdated and DOE needs to update the information on this website.

\section{Conclusion}

For Part II, while the USG agencies listed in this article have information on human trafficking in the United States available on their websites, there are certainly differing levels of comprehensiveness in the agencies' coverage of this topic. Information seekers can best start their exploration on this topic at the U.S. G/TIP website on USG activities, http://www. state.gov/j/tip/response/usg/index.htm, for an overview of the agencies involved in antitrafficking activity in the United States. Over all, the major agencies with high-profile roles and the most comprehensive information and data on this topic are the U.S. G/TIP, Department of Justice, Department of Homeland Security, and Department of Health and Human Services. The U.S. G/TIP and NIJ are the two major grantors for empirical and evaluation research, while DHHS is the major grantor for programs and services to assist trafficked victims in the United States. Last but not least, the two must-read publications are:

1. U.S. Attorney General (2006-2011). Attorney General's Annual Reports to Congress and Assessment of the U.S. Government Activities to Combat Trafficking In Persons: Fiscal Years 2005-2010. Washington, DC: Department of Justice.

2. U.S. Department of State, Office to Monitor and Combat Trafficking in Persons (2001-2012). Trafficking in Persons Reports. Washington, DC: Department of State. In the future, we can expect to see more information on antitrafficking initiatives from the Department of Transportation. 


\section{Notes}

1. The list includes first-time awards and supplements to previous awards. In FY2011, NIJ awarded 387 grants and cooperative agreements for a total of approximately \$207 million. Awards were made in response to 32 solicitations.

2. "How to Use This E-Guide": https://www.ovcttac.gov/TaskForceGuide/EGuide/UseThisGuide. $\underline{\operatorname{aspx}}$

3. ICE's fact sheets: http://www.ice.gov/human-trafficking/factsheets.htm

4. ICE PSAs http://www.ice.gov/human-trafficking/psa.htm

5. See more information on DHHS's Anti-Trafficking in Persons Program at http://www.acf.hhs. gov/programs/orr/programs/anti-trafficking

6. See more information on child soldiers in the U.S. Department of State's 2011 TIP report regarding the list of countries using child soldiers and how the United States will put a limit on certain security assistance and commercial licensing of military equipment to these countries (U.S. Department of State, Office to Monitor and Combat Trafficking in Persons 2011, 12-13). See also Child Soldiers Prevention Act (CSPA) (United States 2007). Although the issue of child soldiers is not emphasized in the DOD's training and policy on trafficking in persons, according to CSPA, there is one relevant concern for the U.S. military personnel as addressed in this CSPA clause: "(14) It is in the national security interest of the United States to reduce the chances that members of the United States Armed Forces will be forced to encounter children in combat situations" (United States 2007, 5). CSPA Section 5: Prohibition, A, also provides details on how the United States can enact sanctions against the countries that violate CSPA by withholding its military and other assistance to these countries (United States 2007, 9-11).

\section{References}

All the websites in this article were accessed on September 28, 2012.

Adams, William, Colleen Owens, Kevonne Small, and U.S. Department of Justice, Office of Juvenile Justice and Delinquency Prevention. 2010. Effects of federal legislation on the commercial sexual exploitation of children. Washington, DC: Government Printing Office. http://permanent.access.gpo.gov/gpo2175/228631. pdf

Banks, Duren, Tracey Kyckelhahn, and United States Bureau of Justice Statistics. 2011. Characteristics of suspected human trafficking incidents, 2008-2010. Bureau of Justice Statistics Special Report. Washington, DC: Government Printing Office. http://www.bjs.gov/content/pub/pdf/cshti0810.pdf

Farrell, Amy, Jack McDevitt, and Stephanie Fahy. 2010. Where are all the victims? Criminology \& Public Policy 9(2): 201-33.

Farrell, Amy, Jack McDevitt, Stephanie Fahy, and Institute on Race and Justice at Northeastern University. 2008. Understanding and improving law enforcement responses to human trafficking: Final report. Boston, MA: Institute on Race and Justice at Northeastern University. https://www.ncjrs.gov/pdffiles1/nij/ grants/222752.pdf

Human Smuggling and Trafficking Center (U.S.). 2004. Charter and amendments: Human Smuggling and Trafficking Center (HSTC). http://www.state. gov $/ \mathrm{m} / \mathrm{ds} /$ hstcenter/41444.htm

Human Smuggling and Trafficking Center (U.S.). 2010. The anatomy of a trafficking ring: Origins and recruitment. Washington, DC: Human Smuggling and Traf- 
ficking Center. HSTC Intelligence Note. Tenancingo Bulletin 1. http://www. state.gov/documents/organization/151384.pdf

Kanetake, Machiko. 2010. Whose zero tolerance counts? Reassessing a zero tolerance policy against sexual exploitation and abuse by UN peacekeepers. International Peacekeeping 17(2): 200-14.

Kyckelhahn, Tracey, Allen J. Beck, Thomas H. Cohen, and United States Bureau of Justice Statistics. 2009. Characteristics of suspected human trafficking incidents, 2007-08. Bureau of Justice Statistics Special Report. Washington, DC: Government Printing Office. http://permanent.access.gpo.gov/lps126320/cshti08. pdf

National Criminal Justice Reference Service (U.S.) and National Institute of Justice (U.S.). 1997-2012. National Criminal Justice Reference Service Abstracts Database. Rockville, MD: NCJRS. https://www.ncjrs.gov/app/abstractdb/abstractdbsearch.aspx

National Institute of Justice (U.S.). 2011. Fiscal year 2011 awards. http://www. nij.gov/funding/awards/2011-table.htm

National Institute of Justice (U.S.). 2012. Topical Collection: Human trafficking. http://nij.ncjrs.gov/App/publications/Pub_search.aspx?searchtype=basic\&c ategory $=99 \&$ location $=$ top $\&$ PSID $=25$

Qu'enivet, No“elle. 2007. The dissonance between the United Nations zero-tolerance policy and the criminalisation of sexual offences on the international level. International Criminal Law Review 7(4): 657-76.

Small, Kevonne, William Adams, Colleen Owens, and Kevin Roland. 2008. An analysis of federally prosecuted CSEC cases since the passage of the Victims of Trafficking and Violence Protection Act of 2000. Washington, DC: Urban Institute, Justice Policy Center. https://0-www.ncjrs.gov.library.unl.edu/pdffiles1/ojjdp/ grants/222023.pdf

United States. 2000. Victims of trafficking and violence protection act of 2000. Washington, DC: Government Printing Office.

United States. 2000a. Victims of trafficking and violence protection act of 2000. Division A: Trafficking victims protection act of 2000. Washington, DC: Government Printing Office.

United States. 2000b. Victims of trafficking and violence protection act of 2000. Division A: Trafficking victims protection act of 2000. Section 108. Minimum standards for the elimination of trafficking. Washington, DC: Government Printing Office.

United States. 2004. Intelligence reform and terrorism prevention act of 2004. Washington, DC: Government Printing Office. http://www.gpo.gov/fdsys/pkg/ PLAW-108publ458/pdf/PLAW-108publ458.pdf

United States. 2007. Child soldier prevention act of 2007. Washington, DC: Government Printing Office. http://www.gpo.gov/fdsys/pkg/BILLS-110s1175is/ pdf/BILLS-110s1175is.pdf

U.S. Attorney General. 2006-2011. Attorney General's Annual Reports to Congress and assessment of the U.S. government activities to combat trafficking in persons: Fiscal years 2005-2010. Washington, DC: Department of Justice. (FY2005-2006: http://cdmresolver.worldcat.org/oclc/176632660/viewonline ; FY20072009: http://cdmresolver.worldcat.org/oclc/467413609/viewonline ; FY2010: 
http://www.justice.gov/ag/annualreports/tr2010/agreporthumantrafficking2010.pdf)

U.S. Attorney General. 2011. Attorney General's Annual report to Congress and assessment of the U.S. government activities to combat trafficking in persons: Fiscal year 2010. Washington, DC: Department of Justice. http://www.justice.gov/ag/ annualreports/tr2010/agreporthumantrafficking2010.pdf

U.S. Congress, House, Committee on Foreign Affairs, Subcommittee on Africa, Global Health, and Human Rights. 2011. The trafficking in persons report 2011: Truth, trends, and tier rankings: Hearing before the Subcommittee on Africa, Global Health, and Human Rights of the Committee on Foreign Affairs, House of Representatives. 112th Cong., 1st sess., October 27, 2011. http://www.gpo.gov/fdsys/ pkg/CHRG-112hhrg70951/html/CHRG-112hhrg70951.htm

U.S. Department of Defense, General Services Administration and National Aeronautics and Space Administration. 2009. Federal acquisition regulation; FAR case 2005-012, Combating trafficking in persons. Federal Register 74(10): 274145. http://www.dodig.mil/SPO/Reports/2005_12_fina_Feb09.pdf

U.S. Department of Defense, Office of the Inspector General. 2004. Statement of Joseph E. Schmitz, Inspector General of the Department of Defense, before the House Committee on Armed Services and the Commission on Security and Cooperation in Europe on implementing the Department of Defense "zero tolerance" policy with regard to trafficking in humans. Washington, DC: Department of Defense, Inspector General. http://www.dodig.mil/fo/JES_TIP_Testimony_092104.pdf

U.S. Department of Defense, Office of the Inspector General. 2011. Evaluation of DoD contracts regarding combating trafficking in persons, U.S. Central Command. Washington, DC: Department of Defense, Inspector General. http://www. dodig.mil/SPO/Reports/SPO-2011-002_508.pdf

U.S. Department of Defense, Office of the Inspector General. 2012. Evaluation of DoD contracts regarding combating trafficking in persons: U.S. European Command and U.S. Africa Command January 17. Washington, DC: Department of Defense, Inspector General. http://www.dodig.mil/SPO/Reports/DODIG-2012-041. pdf

U.S. Department of Health and Human Services. 2012. Look beneath the surface: Posters and brochures. http://www.acf.hhs.gov/programs/orr/resource/ download-campaign-posters-and-brochures

U.S. Department of Health and Human Services. 2012a. Rescue E Restore Campaign fact sheets. http://www.acf.hhs.gov/trafficking/about/factsheets.html

U.S. Department of Health and Human Services. 2012b. Services available to victims of human trafficking: A resource guide for social service providers. September 18. Washington, DC: Department of Health and Human Services. http://www.acf.hhs.gov/programs/orr/resource/ services-available-to-victims-of-human-trafficking

U.S. Department of Homeland Security. 2012. DHS Blue Campaign stakeholder event summary-January 11, 2012. http://www.dhs.gov/xlibrary/assets/ blue-campaign-stakeholder-event-summary.pdf

U.S. Department of Justice, Bureau of Justice Assistance and Office for Victims of Crime. 2011. Anti-Human Trafficking Task Force strategy and operations eguide. 
Washington, DC: Bureau of Justice Assistance and Office for Victims of Crime. https://www.ovcttac.gov/TaskForceGuide/EGuide/Default.aspx.

U.S. Department of Justice, Bureau of Justice Assistance and Office for Victims of Crime. 2009. BJA/OVC Human Trafficking Task Forces (40). https:/ / www. bja.gov/Programs/40HTTF.pdf

U.S. Department of State. 1979-2011. Country reports on human rights practices. Washington, DC: Department of State. http://www.state.gov/j/drl/rls/ hrrpt/index.htm (1999-2011), and http://www.state.gov/www/global/human_rights/hrp_reports_mainhp.html (1993-1999).

U.S. Department of State, Office to Monitor and Combat Trafficking in Persons. 2001-2012. Trafficking in persons reports. Washington, DC: Department of State. http://www.state.gov/j/tip/rls/tiprpt

U.S. Department of State, Office to Monitor and Combat Trafficking in Persons. 2007. Trafficking in persons and international military organizations. Washington, DC: Department of State. http://www.usfk.mil/usfk/Uploads/120/pht.pdf

U.S. Department of State, Office to Monitor and Combat Trafficking in Persons. 2011a. Trafficking in persons report 2011. Washington, DC: Department of State. http://www.state.gov/j/tip/rls/tiprpt/2011/index.htm

U.S. Department of State, Office to Monitor and Combat Trafficking in Persons. 2011b. U.S. government entities combating human trafficking. http://www.state. gov/j/tip/response/usg/index.htm

U.S. Federal Bureau of Investigation. 2012. Local FBI offices. http:/ / www.fbi.gov/ contact-us/field

U.S. Immigration and Customs Enforcement. 2010. Continued presence: Temporary immigration status for victims of human trafficking. Washington, DC: U.S. Immigration and Customs Enforcement. http://www.ice.gov/doclib/humantrafficking/pdf/continued-presence.pdf

\section{Appendix A: Additional Resources on Human Trafficking}

Selected Resources on Antitrafficking Efforts in the United States

- National Association of Attorneys General's Presidential Initiative. Pillars of hope: Attorneys General unite against human trafficking: http://www.naag. org/2011-2012-presidential-initiative.php

- Polaris Project: http://www.polarisproject.org National Human Trafficking Resource Center (Hotline number): http://www.polarisproject.org/what-we-do/national-human-trafficking-hotline/the-nhtrc/ overview :1-888-3737-888

- Freedom Network USA (an NGO coalition): http:// www.freedomnetworkusa. org

- Human Trafficking Database at the University of Michigan Law School: http:// www.law.umich.edu/clinical/HuTrafficCases/Pages/searchdatabase.aspx

- UNL Interdisciplinary Conference on Human Trafficking: http://digitalcommons.unl.edu/humantrafficking 
Selected Resources on International Antitrafficking Efforts

- United Nations. Global Initiative to Fight Human Trafficking (U.N. GIFT): http://www.ungift.org/knowledgehub

- United Nations Inter-Agency Project on Human Trafficking (UNIAP): http:// www.no-trafficking.org

- Human Rights Watch. Trafficking of Women and Girls: http:/ / www.hrw.org/ category/topic/women \%E2\% 80\%99srights/trafficking-women-and-girls

- International Organization for Migration. Counter-Trafficking: http://www. iom.int/jahia/page748.html

- International Labor Organization.

- Topics: child labor, domestic workers, forced labor, etc., http://www.ilo. org/global/topics/lang-en/index.htm

- Preventing human trafficking in the GMS (Mekong Region), http://www. ilo.org/public/english/region/asro/bangkok/child/trafficking/index. $\underline{\mathrm{htm}}$

- UNICEF: Child trafficking: http://www.unicef.org/protection/57929 58005. $\underline{\mathrm{html}}$

- Save the Children: http://www.savethechildren.org/site/c.8rKLIXMGIpI4E/ b.6192517/k.9ECD/Protecting_Children_from_Exploitation.htm

- Chab Dai: http://www.chabdai.org/home.html

- LOVE146: http://love146.org

- Nexus Institute: http://www.nexusinstitute.net

- UNL Interdisciplinary Conference on Human Trafficking: http:// digitalcommons.unl.edu/humantrafficking 